\title{
Status of white-necked picathartes - another reason for the conservation of the Peninsula Forest, Sierra Leone
}

\author{
Hazell S. S. Thompson
}

\begin{abstract}
A survey of the Western Area Peninsula Forest in Sierra Leone in 1990 located eight breeding sites of the white-necked picathartes - a striking endemic West African forest bird threatened with extinction. Several breeding sites were in areas of fairly intense human activity and in danger of imminent destruction. Subsequent observations revealed successful breeding in 1990 and unsuccessful attempts in 1991. This population is probably only just viable. The discovery of Jentink's duiker - Africa's rarest duiker - in the same forest in 1988 and the presence of three threatened primate species prompted calls for urgent conservation action. The precarious status of the white-necked picathartes population provides another compelling reason for such action.
\end{abstract}

\section{Introduction}

The white-necked picathartes Picathartes gymnocephalus occurs only in the forests of West Africa, from Guinea to Ghana, and forms a superspecies with the only other member of the genus, the grey-necked picathartes $P$. oreas, which is endemic to the forests of Cameroon, Nigeria, Gabon and Bioko. The two species have an unusual nesting ecology, building mud nests on rock faces, cave roofs and cliff overhangs below closed canopy forest.

The white-necked picathartes is threatened with extinction by the rapid fragmentation and destruction of its forest habitat mainly as a consequence of farming, timber extraction and fuelwood collection. Survival of the species in the long term may only be ultimately possible in Sierra Leone and Ghana (Collar and Stuart, 1985; Allport, 1991).

There have been casual reports of whitenecked picathartes from the Western Area Peninsula Forest (WAPF) since 1912 (Collar and Stuart, 1985), and until the 1970s it was considered as 'not uncommon' in the area (Field, 1974). There has been massive degradation and destruction of the forest since then, with extensive illegal encroachment into the forest reserve. The most recent previous reports of picathartes in the WAPF date from the early 1980s (A. Tye, pers. comm; Willis, 1983). The survey reported here constitutes the first systematic search for white-necked picathartes in the WAPF.

The WAPF (a non-hunting forest reserve) is less than $5 \mathrm{~km}$ south of Freetown (population 470,000: 1985), the capital city of Sierra Leone. It is the westernmost area of closed-canopy forest left in the country and consists of a forested chain of hills running parallel to the coast, about $37 \mathrm{~km}$ long and $14 \mathrm{~km}$ wide and separated from the Atlantic Ocean by a narrow coastal plain (Figure 1).

\section{Picathartes survey}

A total of 141 hours were spent searching for picathartes breeding sites in the WAPF during March and April 1990. The survey method consisted of walking along stream or river beds, which were dry at that time of the year, and searching the banks and river valley slopes wherever there were big rocks for the characteristic mud nests. Extensive surveys were also made along forest paths and, with 


\section{H. S. S. THOMPSON}

the help of pictures of the bird, local people were questioned about its presence.

Eight breeding sites were discovered during the survey, two of them by ornithologists who were carrying out a general avifuanal survey for the Royal Society for the Protection of Birds (RSPB) (Wood and Ausden, 1990). Only five of 18 nests found showed any signs of recent use, i.e. fresh mud layers or presence of nest lining. These 'active' nests were at only two 'colonial' sites. The remaining six sites each consisted of a solitary nest. This is in contrast to what has been found in white-necked picathartes populations elsewhere: colonial breeding has usually been found to be the rule rather than the exception (Grimes, 1964; Allport et al., 1989; Thompson, 1990).

Three of the eight breeding sites (including a site at which successful breeding occurred in 1990) were less than $50 \mathrm{~m}$ from frequently used footpaths and in one case, a major road.
However, residents and itinerant hunters were largely unaware of the presence of the species. Only two respondents of more than 25 people questioned recognized pictures of the bird or claimed to have seen it.

\section{Breeding}

The contents of nine nests at four sites were inspected periodically from May 1990 onward. Intensive observations were carried out at one site containing three nests, for a total of 95 hours between June and September, using 10 $\times .30$ binoculars and a $60 \times 22$ telescope from a hide $20-30 \mathrm{~m}$ away. All the other sites were visited at least once a week.

Two of the four sites monitored were not used during 1990 and 1991, and only four of a total of seven available nests at the active sites were used for breeding in 1990 . Nest repair

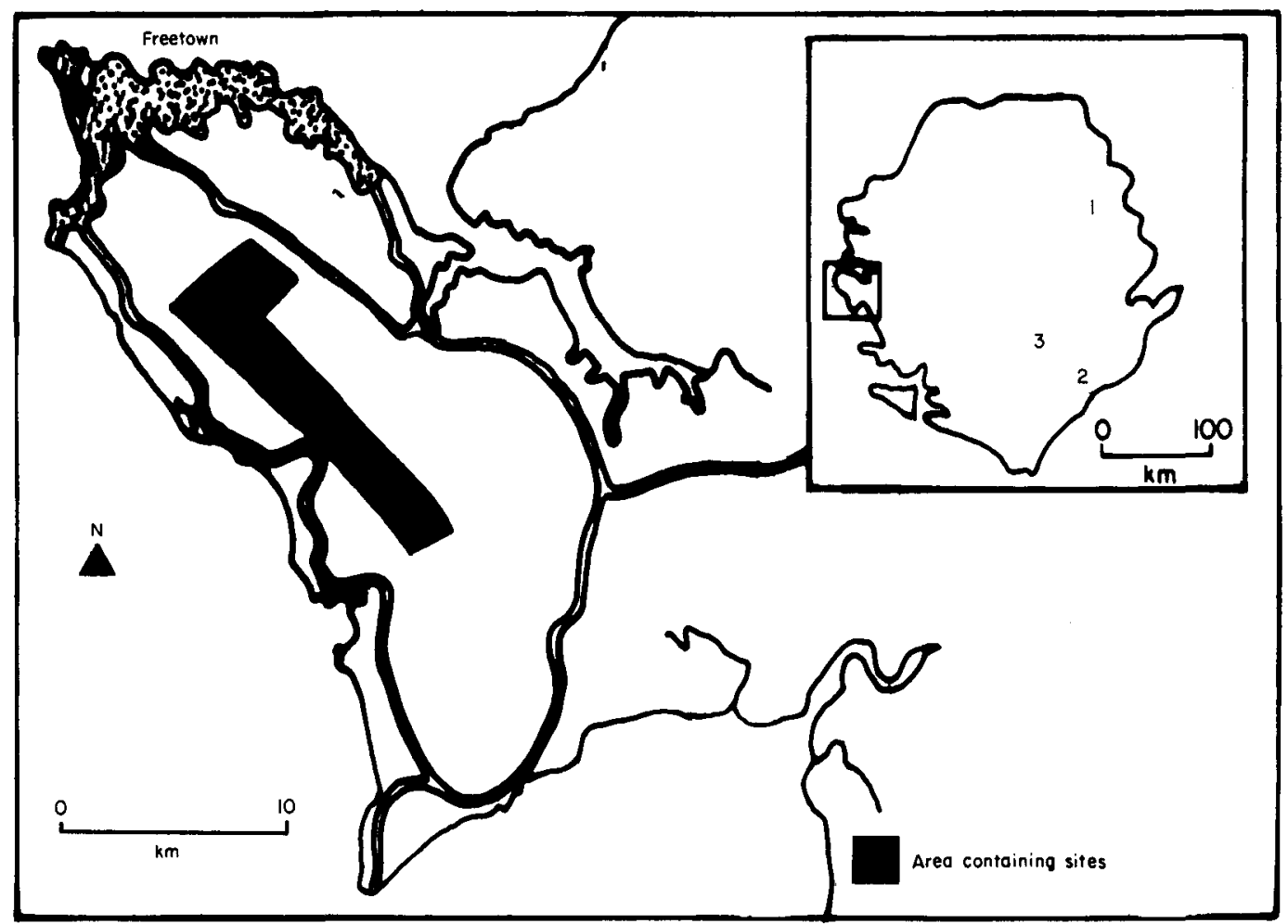

Figure 1. Freetown Peninsula showing the area containing picathartes sites. Inset map shows other areas in Sierra Leone in which the presence of the species has been recently confirmed: 1, Loma Mountains; 2, Gola Forest; 3, Kambui Hills. 
White-necked picathartes (H. Thompson).

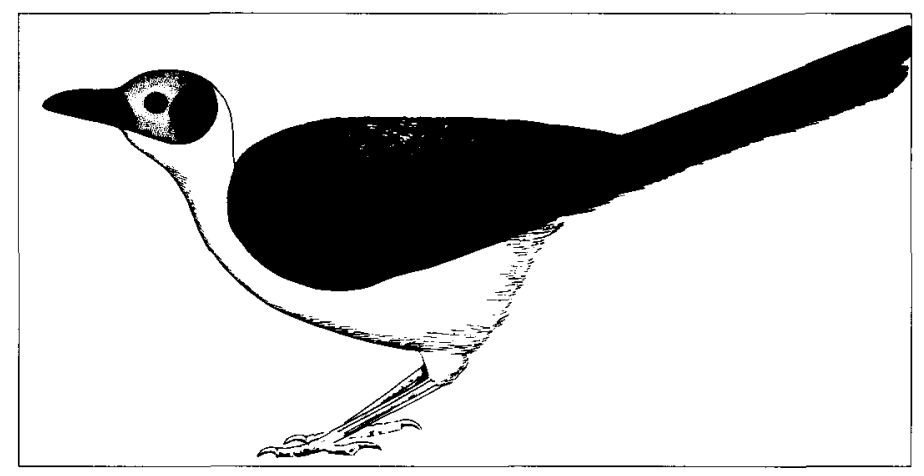

was initiated in June in both years and eggs and/or young were found in these nests in June, August and September 1990, i.e. during the May-October wet season. A total of seven eggs was laid in the four nests, with not more than two per nest. Four of the seven eggs hatched, but only two nestlings survived to fledge. Broken eggshells below nests usually indicated egg loss but some nestlings disappeared without trace. The reasons for these losses are as yet unknown. There was no sign of breeding activity during the dry season from October to April; adult birds were seldom seen at the breeding sites during this period.

In 1991 attendance of adult birds at the nests increased in frequency and duration from June (when birds were absent from the nests during our 1-hour visits each week) to September (when on average two birds were seen per visit), but no eggs were detected. On 21 September remains of picathartes eggshells were found on the ground below three fully repaired and lined nests indicating that eggs had been laid and lost between weekly visits on the 14 and 21 September. There was no further evidence of breeding in 1991.

\section{Other populations in Sierra Leone}

A substantial white-necked picathartes population is known to exist in the Gola Forest in south-eastern Sierra Leone (Figure 1). Fortysix breeding sites containing 311 nests were discovered and mapped between 1988 and 1991 (Allport et al., 1989; Thompson, 1991).
The species has also been found recently in the Kambui Hills Forest Reserve (Thompson, 1991) and the Loma Mountains (pers. obs., 1992). There are old records from Tingi Hills and the species probably occurs in the Kangari Hills and Tama-Tonkoli Forest Reserves (Collar and Stuart, 1985). In 1992 a nation-wide survey funded by the RSPB, Fauna and Flora Preservation Society (FFPS) and the Frank Chapman Memorial Fund was carried out to locate picathartes colonies throughout Sierra Leone and estimate population densities.

\section{Conservation}

Although the major stronghold of the whitenecked picathartes in Sierra Leone is in the Gola Forest, the proximity of the WAPF population to Freetown and its consequent potential for the integration of wildlife conservation with eco-tourism greatly enhances its importance. However. tourism is only a distant possibility at present. It will depend on the results of current research, and also on the protection and recovery of the picathartes population, which could take 10 years. The WAPF picathartes population must be small; low breeding success in 1990 coupled with the fact that breeding was not detected in 1991, and the large number of apparently abandoned old sites suggest that this population is in decline. One of the two active sites at which breeding occurred in 1990 will almost certainly be destroyed in the near future because it is close to frequently used footpaths in an area where wood-cutting is intense. On the 
other hand, the existence of picathartes in such a disturbed habitat suggests a higher threshold to disturbance than has hitherto been suspected (Collar and Stuart, 1985). Thus, although the WAPF population lies on the brink of extinction, urgent action could save it.

There have been numerous previous recommendations for conservation action in the WAPF; the most recent being that of Davies and Birkenhager (1990), who confirmed the presence of Jentink's duiker Cephalophus jentinki in the forest. This discovery and the presence of three threatened primates - diana monkey Cercopithecus diana, red colobus Procolobus badius and western chimpanzee Pan troglodytes (Lee, Thornback and Bennett, 1988) as well as the threatened status of the whitenecked picathartes population, are sufficient reasons for conservation action. In addition, the importance of the continued existence of the forest for the protection of the Freetown water reservoir catchment area as well as for the success of a budding tourist industry is no longer in doubt (Phillipson, 1978; Davies and Birkenhagar, 1990; Wood and Ausden 1990). A first step in conservation action should be the reinforcement of the overstretched Wildlife and Forestry Division personnel (Ministry of Agriculture and Forestry) in this area. Enforcement of existing regulations would minimize encroachment and exploitation of the forest. This would at least extend the life of the forest and the white-necked picathartes population. However, ideal action would entail speedy implementation of recent recommendations (Phillipson, 1978; Stuart and Adams, 1990) that the WAPF be upgraded to a national park, thus tapping its excellent educational and tourism potential while maintaining its ecological and conservation value.

\section{Acknowledgments}

The survey was funded by the Royal Society for the Protection of Birds (RSPB) through the International Council for Bird Preservation (ICBP). I am grateful to P. N. Wood, M. Ausden and E. Johnson for valuable assistance in the field.

\section{References}

Allport, G, 1991. The status and conservation of threatened birds in the Upper Guinea forest. Bird Conservation International, 1, 53-74.

Allport, G., Ausden, M., Hayman, P.V., Robertson, P. and Wood, P. 1989. The Conservation of Gola Forest, Sierra Leone. ICBP Study Report No. 38, ICBP, Cambridge, England.

Collar, N.J. and Stuart, S.N. 1985. Threatened Birds of Africa and its Related Islands. ICBP/IUCN Red Data Book, Part 1, 3rd edn. ICBP/IUCN, Cambridge, England.

Davies, G. and Birkenhager, B. 1990. Jentink's duiker in Sierra Leone: evidence from the Freetown Peninsula. Oryx, 24, 143-146.

Field, G.D. 1974. Birds of Freetown Peninsula. Fourah Bay College Bookshop Limited, Mount Aureol, Freetown, Sierra Leone.

Grimes, L. 1964. Some notes on the breeding of Picathartes gymnocephalus in Ghana. Ibis, 106, 258-261.

Lee, P.C., Thornback, J. and Bennett, E.L. 1988. Threatened Primates of Africa: The IUCN Red Data Book. IUCN, Gland, Switzerland.

Phillipson, J.A. 1978. Wildlife Conservation and Management in Sierra Leone. Special Report to MANRF, Freetown.

Stuart, S.N. and Adams, R.J. 1990. Biodiversity in Sub-Saharan Africa and its Islands: Conservation, Management and Sustainable Use. Occasional Papers of the IUCN Species Survival Commission No.6. IUCN, Gland, Switzerland.

Thompson, H. 1990. Progress Report on a Pilot Study of Picathartes gymnocephalus in the Gola Forest and the Western Area Peninsula Forest, Sierra Leone., June-September 1990. Unpubl. report to RSPB/ICBP.

Thompson, H. 1991. Ecology and Conservation of the White-necked Picathartes, Picathartes gymnocephalus, in Sierra Leone. Progress Report: March-November 1991. Unpubl. report to RSPB/ICBP.

Willis, E.O. 1983. Wrens, gnatwrens, rockfowl, babblers and shrikes (Troglodytidae, Polioptilidae, Picathartidae, Timaliidae and Laniidae) as ant-followers. Le Gerfaut, 73, 393-404.

Wood, P. and Ausden, M. 1990. The Wildlife of the Western Area Forest, Sierra Leone. Special Report to MANRF, Sierra Leone for ICBP/RSPB.

Hazell S. S. Thompson, Department of Zoology, Fourah Bay College, University of Sierra Leone, Mount Aureol, Freetown, Sierra Leone. 